Louisiana State University

LSU Digital Commons

$12-1-2005$

\title{
Cryopreservation of human hematopoietic stem and progenitor cells loaded with trehalose: Transient permeabilization via the adenosine triphosphate-dependent $\mathrm{P} 2 \mathrm{Z}$ receptor channel
}

\author{
Sandhya S. Buchanan \\ University of Colorado Denver \\ Michael A. Menze \\ Louisiana State University \\ Steven C. Hand \\ Louisiana State University \\ David W. Pyatt \\ Summit Toxicology \\ John F. Carpenter \\ University of Colorado Denver
}

Follow this and additional works at: https://digitalcommons.Isu.edu/biosci_pubs

\section{Recommended Citation}

Buchanan, S., Menze, M., Hand, S., Pyatt, D., \& Carpenter, J. (2005). Cryopreservation of human hematopoietic stem and progenitor cells loaded with trehalose: Transient permeabilization via the adenosine triphosphate-dependent P2Z receptor channel. Cell Preservation Technology, 3 (4), 212-222. https://doi.org/10.1089/cpt.2005.3.212 


\section{University of Louisville}

From the SelectedWorks of Michael A. Menze

Winter 2005

\section{Cryopreservation of Human Hematopoietic Stem and Progenitor Cells Loaded with Trehalose: Transient Permeabilization via the Adenosine TriphosphateDependent P2Z Receptor Channel}

Sandhya S. Buchanan

Michael A Menze, University of Louisville

Steven C. Hand

David W. Pyatt

John F. Carpenter 


\title{
Frontiers in Clinical Research
}

\section{Cryopreservation of Human Hematopoietic Stem and Progenitor Cells Loaded with Trehalose: Transient Permeabilization via the Adenosine Triphosphate- Dependent P2Z Receptor Channel}

\author{
SANDHYA S. BUCHANAN, ${ }^{1}$ MICHAEL A. MENZE, ${ }^{2}$ STEVEN C. HAND, ${ }^{2}$ \\ DAVID W. PYATT, ${ }^{3}$ and JOHN F. CARPENTER ${ }^{1}$
}

\begin{abstract}
Hematopoietic stem and progenitor cells (HPCs) are a heterogenic population of cells used to treat a number of human diseases. Multilineage differentiation is a required function in successful hematopoietic reconstitution after transplantation of cryopreserved grafts. Conventional use of the cryoprotectant dimethyl sulfoxide (DMSO) has resulted in some reports of infusion related toxicity attributed to DMSO and/or damage to cells during freezethawing procedures. The purpose of this study was to explore the use of trehalose, a nontoxic disaccharide of glucose, as an alternative cryoprotectant. Trehalose was introduced into HPCs using the P2Z receptor, known to form nonselective pores in the presence of extracellular adenosine $5^{\prime}$-triphosphate $\left(\mathrm{ATP}^{4-}\right)$. Cells loaded with trehalose were frozen and stored at $-80^{\circ} \mathrm{C}$ for 4 months. After storage, cells were thawed and evaluated for differentiation capacity and clonogenic output. Results obtained with this technique were compared to traditional freezing protocols using $10 \%(\mathrm{v} / \mathrm{v})$ DMSO. Clonogenic output of cells frozen with trehalose was approximately $90 \%$ of that of unfrozen control cells. Furthermore, there were no significant alterations in phenotypic markers of differentiation, activation, and proliferation. These data demonstrate that preservation of HPC function with trehalose is superior to that obtained with DMSO and this method could be widely adapted to any cell or tissue type expressing the $\mathrm{P} 2 \mathrm{Z}$ receptor. Furthermore, cells loaded with trehalose can potentially be freeze-dried for storage at ambient temperatures.
\end{abstract}

\section{INTRODUCTION}

T HE THERAPEUTIC USE of hematopoietic stem and progenitor cells (HPCs) to treat a variety of human diseases, has led to a critical need for more effective cryopreservation procedures. ${ }^{1}$ These freeze-thawing protocols for all clinically relevant cellular products must not only result in high recoveries (e.g., $>90 \%$ ) of viable, functional cells but also must be designed to minimize adverse responses in patients. Currently, HPCs are cryopreserved in high concentrations (e.g., 1-2 M) of dimethyl sulfoxide (DMSO). ${ }^{2,3}$ Cell preparations are then

\footnotetext{
${ }^{1}$ Center for Pharmaceutical Biotechnology and Department of Pharmaceutical Sciences, University of Colorado at Denver and Health Sciences Center, Denver, Colorado.

${ }^{2}$ Division of Cellular, Developmental and Integrative Biology, Department of Biological Sciences, Louisiana State University, Baton Rouge, Louisiana.

${ }^{3}$ Summit Toxicology, Lafayette, Colorado.
} 
thawed and can be transfused directly into a patient without removing the DMSO, which is a likely cause of adverse effects and toxicity. ${ }^{4-6}$ Efforts to improve safety measures include DMSO removal prior to transfusion by timeconsuming wash protocols, which can result in decreased recovery of viable cells. ${ }^{2-4,7,8}$ Because the absolute number of HPCs is the best predictor of the clinical efficacy of the graft, ${ }^{9}$ reduction in cell recoveries can affect patient outcomes. Therefore, an effective nontoxic cryoprotectant, which does not need to be removed from the graft prior to transfusion, would be of significant clinical benefit.

Cell membranes are impermeable to many nontoxic alternative cryoprotectants (e.g., sucrose or trehalose), and therefore the intracellular concentrations required for effective cryopreservation usually cannot be achieved. Several approaches have been developed to increase the levels of intracellular trehalose including molecular engineering, ${ }^{10}$ manipulating lipid phase transitions, ${ }^{11}$ and fluid phase endocytosis. ${ }^{12}$ Toner and colleagues have developed an innovative approach that uses a genetically engineered $\alpha$-hemolysin derived from Staphylococcus aureus to permeabilize mammalian cells to compounds such as sucrose or trehalose. ${ }^{13,14}$ Eroglu et al. ${ }^{14}$ used this approach to introduce trehalose to human keratinocytes for the purpose of cryopreservation. This method was then used to develop a novel poration technique and cryopreservation method for HPCs using trehalose. ${ }^{15}$ Colony-forming units (CFUs) generated from cells frozen and thawed with intra-cellular and extracellular trehalose were essentially equivalent in size, morphology, and number to those generated by unfrozen control cells. Additionally, there were no observable alterations in phenotypic markers of differentiation. Taken together, the studies with the exogenous pore protein provide "proof-of-principal" data for the general utility of using transient poration of cell membranes to increase the levels of disaccharide cryoprotectants inside cells.

Although the use of an exogenous, bacteriaderived pore protein would allow effective permeabilization and cryopreservation of various cell types, it would be necessary to remove the pore protein prior to clinical use to avoid a po- tential adverse immunological response in patients. In the current study we have investigated permeabilization of cells to trehalose with an endogenous cell surface receptor, termed $\mathrm{P} 2 \mathrm{Z}^{16,17}$ (synonymous with $\mathrm{P} 2 \mathrm{X}_{7}$ ). ${ }^{18} \mathrm{In}$ the presence of millimolar concentrations of extracellular adenosine triphosphate (ATP), this protein forms an indiscriminate pore that renders the plasma membrane permeable to small molecules (e.g., molecular weight $[\mathrm{MW}] \leq 900$ Da). ${ }^{19,21}$ Addition of magnesium to complex with the ATP reverses this effect, so that cells can be permeabilized transiently. ${ }^{22}$ Indeed, membrane-impermeant metabolic effectors have been loaded into J774 macrophages via the P2Z channel with retention of high cellular viability ${ }^{23,24}$ as well as large quantities of trehalose (G. Elliot, J. Cusick, M.A. Menze, T. Witt, S.C. Hand, and M. Toner, unpublished observations).

$\mathrm{P} 2 \mathrm{Z}$ is expressed in many hematopoietic cells including myeloid progenitors, $\mathrm{CD} 34^{+}$peripheral blood progenitor cells as well as mature cell types such as granulocytes, neutrophils, monocytes/macrophages, lymphocytes, dendritic, and erythrocytes. ${ }^{19,25-27}$ In the current study, we used a model cell line for HPCs (TF1 cells) that we determined expresses the P2Z receptor. TF-1 cells are cytokine-dependent, CD34-positive, and retain the ability to differentiate in culture down erythroid, monocytic, and megakaryocytic lineages after proper stimulation. ${ }^{28}$ These characteristics make TF-1 cells an appropriate surrogate for primary experiments designed to evaluate the effects of $\mathrm{P} 2 \mathrm{Z}$ receptor-mediated permeabilization and cryopreservation on cell survival and differentiation.

\section{MATERIALS AND METHODS}

\section{Cell culture}

TF-1 cells (cell line: CRL-2003; American Tissue Culture Collection, Manassas, VA) were cultured in RPMI complete medium (RPMI 1640, $2 \mathrm{mM}$ L-glutamine, $5 \mathrm{mM}$ glucose, $10 \mathrm{mM}$ HEPES, $10 \mathrm{mM}$ penicillin, $10 \mathrm{mM}$ streptomycin, $10 \%$ fetal bovine serum [FBS], bovine serum albumin [BSA], $1 \mathrm{mM}$ sodium pyruvate and 2 
$\mathrm{ng} / \mathrm{mL}$ granulocyte-macrophage colony-stimulating factor [GM-CSF; University Hospital Pharmacy, Denver, CO]. Culture medium was changed every 2 days; after centrifugation and the removal of old media. Growing cells were resuspended at a density of $2-3 \times 10^{5}$ cells $/ \mathrm{mL}$. Cells used for permeability studies were between passage 2 and 12 and cells used for cryopreservation studies were between passage 2 and 9 . The cells were discarded after the twelfth passage.

\section{Expression of $\mathrm{P} 2 \mathrm{Z}$ receptor on $\mathrm{TF}-1$ cells}

Expression of $\mathrm{P} 2 \mathrm{Z}$ receptor was measured by permeabilizing TF-1 cells with BD Cytofix/Cytoperm kit (BD Biosciences Pharmingen, San Diego, CA) using manufacturer's instructions, staining with anti-P2Z/P2X7 receptor (Calbiochem, La Jolla, CA) polyclonal antibody from rabbit and anti-rabbit-PE secondary antibody developed in goat (Sigma, St. Louis, MO). Briefly, $1 \times 10^{6}$ TF- 1 cells were washed twice with $1 \mathrm{~mL}$ of staining buffer (phosphatebuffered saline [PBS]/1\% FBS/0.05\% [w/v] sodium azide). Cells were pelleted by centrifugation (1100 rpm for $8 \mathrm{~min}$ ) and then resuspend in $250 \mu \mathrm{L}$ of BD Cytofix/Cytoperm solution for $30 \mathrm{~min}$ at $4^{\circ} \mathrm{C}$ to fix cells. Cells were washed twice in $1 \mathrm{~mL}$ of $1 \times \mathrm{BD}$ Perm/Wash solution. Cells were then thoroughly resuspended in 50 $\mu \mathrm{L}$ of BD Perm/Wash solution containing antiP2Z/P2X7 (1:100) for $30 \mathrm{~min}$ at $4^{\circ} \mathrm{C}$. Cells were washed twice in $1 \mathrm{~mL}$ of $1 \times \mathrm{BD}$ Perm/Wash solution. Cells were then resuspended in $50 \mu \mathrm{L}$ of $1 \times \mathrm{BD}$ Perm/Wash solution containing 20 $\mu \mathrm{L}$ of anti-rabbit-PE for 30 minutes at $4^{\circ} \mathrm{C}$ in the dark. Cells were washed twice in $1 \mathrm{~mL}$ staining buffer. Cells were then resuspended in $300 \mu \mathrm{L}$ of staining buffer and stored at $4^{\circ} \mathrm{C}$ in the dark until flow cytometric analysis. Flow cytometric analysis was performed with a Coulter FC500 equipped with CXP software.

\section{Poration efficiency}

TF-1 cells were harvested in the log phase of growth following standard methods. TF-1 cells were incubated in poration buffer $(5 \mathrm{mM}$ glucose, $1 \times$ essential amino acids, $1 \times$ nonessential amino acids, and $1 \times$ Vita Stock at pH 7.45 [modified from Menze et al. ${ }^{23}$ ]) containing 5
mM ATP, $200 \mathrm{mM}$ trehalose, and $100 \mu \mathrm{L}$ of fluorescein isothiocyanate (FITC; $0.1 \mathrm{mg} / \mathrm{mL}$ ). FITC is an impermeable fluorescent dye used to quantitate poration efficiency. Pores were closed with the addition of $1 \mathrm{mM} \mathrm{MgSO}_{4}$ and 10-fold dilution of ATP using RPMI. Each sample contained $1 \times 10^{6}$ cells in $1 \mathrm{~mL}$ of porating buffer. Control cells were treated in an identical manner without the addition of ATP.

After poration and trehalose loading, TF-1 cells were washed twice with PBS $/ 5 \%$ FBS and resuspended in $500 \mu \mathrm{L}$ of PBS/1\% FBS containing $10 \mu \mathrm{L}$ of PI $(1 \mathrm{mg} / \mathrm{mL})$. Samples were analyzed for viability in addition to the presence and intensity of FITC using a Coulter Epics XL flow cytometer equipped with System II software.

\section{Determination of optimal processing conditions}

Optimal processing conditions were first established by determining the trehalose-loading concentration offering the highest CFU after freeze-thawing. TF-1 cells were incubated in the presence of increasing concentrations of trehalose $(0-600 \mathrm{mM})$ for $60 \mathrm{~min}$ at $37^{\circ} \mathrm{C}$ with 5 $\mathrm{mM}$ ATP. Control cells were incubated under the same conditions without trehalose. Samples were placed in Nalgene cryotubes and frozen in complete medium containing either the same trehalose concentration as the poration condition or in 10\% (vol/vol) DMSO (1.4 $\mathrm{M})$ and $0.025 \%$ of human serum albumin (HSA). Cryotubes were transferred to a Nalgene cryogenic controlled-rate freezing container (Fisher Scientific, Atlanta, GA). It was placed in a $-80^{\circ} \mathrm{C}$ freezer, and stored there for 4 months at $-80^{\circ} \mathrm{C}$. Frozen cells were rapidly thawed in a $37^{\circ} \mathrm{C}$ water bath and allowed to rest for $1 \mathrm{~h}$ at room temperature in laminarflow hood. Function of TF-1 cells after freezethawing was determined by CFU assay. Control cells frozen in DMSO were transferred directly to methylcellulose (final DMSO concentration was $0.2 \%$ [vol/vol]).

To ascertain the efficacy of trehalose as a cryoprotectant, cells were frozen with the determined optimal trehalose concentration in a final volume of $1 \mathrm{~mL} \mathrm{RPMI/20 \%} \mathrm{FBS} \mathrm{under} \mathrm{one}$ of the following experimental conditions: extracellular trehalose $(200 \mathrm{mM})$, intracellular 
trehalose (200 $\mathrm{mM}$ in porating buffer), and intra/extracellular trehalose $(200 \mathrm{mM})$. Function of TF-1 cells after freeze-thawing was determined by CFU assay.

\section{Colony-forming unit assay}

Progenitor cell proliferation of thawed cells was detected by an established in vitro method using a semisolid methylcellulose system (StemCell Technologies, Vancouver, British Columbia, Canada) measuring clonogenic output via CFU. Frozen TF-1 cells were rapidly thawed $\left(37^{\circ} \mathrm{C}\right.$ water bath), counted, and approximately $2 \times 10^{3}$ cells $/ \mathrm{mL}$ were transferred to methylcellulose. Freshly cultured, unfrozen cells served as positive controls. All samples were established with quadruplicate plates and cultured at $37^{\circ} \mathrm{C}$ in humidified air containing $5 \% \mathrm{CO}_{2}$ for 14 days, after which colonies were enumerated on an inverted Nikon microscope ( 1 colony contains a minimum of 50 cells).

\section{Viability assays}

Cells were assayed for viability by trypan blue (TB) exclusion or flow cytometric analysis using propidium iodide (PI). For TB exclusion, $100 \mu \mathrm{L}$ of cells were diluted 1:5 (100 $\mu \mathrm{L}$ cells:100 $\mu \mathrm{L}$ TB:300 $\mu \mathrm{L}$ PBS). Cells negative for TB were considered live and those that stained blue were considered dead. Cell viability/poration efficiency was assessed by FITC/PI staining using flow cytometry. Briefly, porated cells were loaded with trehalose and FITC. Pores were closed and excess dye was removed by washing twice with PBS/1\% FBS. Subsequently, $1 \times$ $10^{5}$ porated cells were removed and suspended in $500 \mu \mathrm{L}$ of PBS/1\% FBS. After pores were closed, cellular viability was monitored using a membrane-impermeant dye, PI, which labels the nucleic acids of membrane-compromised cells. Cells were treated with $10 \mu \mathrm{L}$ of 1.0 $\mathrm{mg} / \mathrm{mL}$ PI for $4 \mathrm{~min}$ prior to analysis. Cells that stained positive for FITC and negative for PI were gated and considered to be both viable and porated, whereas cells stained with PI were gated as dead. All reported viability was normalized to total cell count. Flow cytometric analysis was performed on a Coulter Epics XL equipped with System II software.

\section{Phenotypic analysis of surface antigens}

After poration, experimental cells were stained with a cocktail of three monoclonal antibodies $(\mathrm{mAb})$ conjugated to three discrete fluorophores: CD34-PerCp, CD38-PE, and CD71FITC (BD Biosciences Pharmingen). Additional fluorophores investigated were CD33-PE and CD235a-PE (glycophorin A). Approximately $1 \times 10^{5}$ porated cells were incubated with the antibody cocktail for $30 \mathrm{~min}$ at $4^{\circ} \mathrm{C}$, washed twice with $\mathrm{PBS} / 5 \% \mathrm{FBS}$, and resuspended in PBS/1\% FBS. Following standard flow cytometric protocols, three-color analysis analyses of these three phenotypic markers was conducted simultaneously with a Coulter Epics XL equipped with System II software. The isotype controls IgG-PerCp, IgG-PE, and IgG-FITC were also purchased from BD Biosciences Pharmingen.

\section{Statistical analysis}

Statistical analysis was performed on viability, immunophenotype and CFU assay results using student SigmaPlot 2001. Differences among groups were considered significant when $p$ values were less than 0.05. CFU experiments were repeated three times with quadruplicates. Poration efficiency, viability, and immunophenotype were repeated three times with triplicates. Data reported are means of survival rates representing the standard deviation from the mean.

\section{RESULTS AND DISCUSSION}

\section{Expression of P2ZR and permeabilization of TF-1 cells}

We investigated the expression of $\mathrm{P} 2 \mathrm{Z}$ receptor on TF-1 cells using indirect staining and flow cytometric analysis (Fig. 1). Staining with secondary antibody alone marked the background fluorescence level by nonspecific binding of this antibody to dead or other cells $(1.1 \% \pm 0.3 \%$, Fig. 1A). Fluorescence levels above the background were considered specific for P2Z and shown to be approximately $86 \% \pm 5 \%$ (Fig. 1B) compared to secondary antibody alone (overlay of A and B as shown in Fig. 1C). 

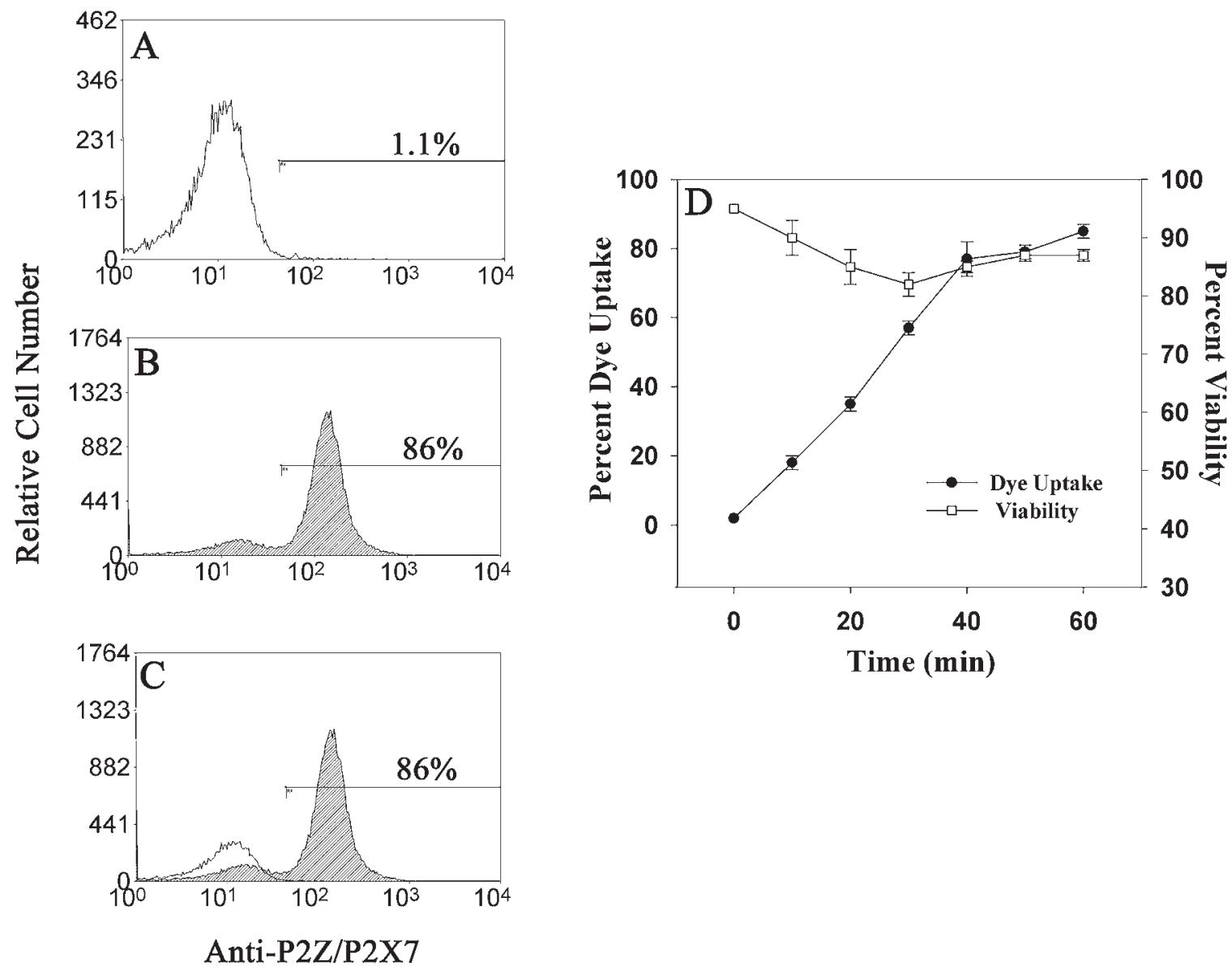

Time (min)

FIG. 1. Expression of P2Z receptor and dye uptake by porated TF-1 cells. Expression of P2Z receptor was measured by immunofluorescence and analyzed by flow cytometry. (A) Negative control by treatment with secondary antibody alone signifying nonspecific binding or background fluorescence (approximately 1.1\%). (B) Cells stained with antiP2Z showed approximately $86 \%$ of TF-1 cells express the P2Z receptor compared to control cells. (C) Overlay of (A) and (B) showing comparison of background fluorescence to cells positive for P2Z. (D) Dye uptake and viability of porated TF-1 cells. Dye uptake (closed circles) during permeabilization was measured by determining fluorescein isothiocyanate (FITC)-positive cells with flow cytometry. Viability of porated cells (open squares) was measured by quantifying propidium iodide-negative cells with flow cytometry. Dye uptake and viability values are represented as the mean \pm standard deviation of three independent experiments, each with triplicate samples.

Experimental conditions are critically important to allow effective transfer of solute into the cells, and ensure maintenance of cell viability. These parameters were optimized by using dye uptake to characterize permeabilization. FITC was used as an indicator of poration because it is impermeable to cellular membranes and has a similar molecular mass (MW 389) to that of trehalose (MW 342). As shown in Figure 1D (solid circles), as a function of permeabilization time (up to $40 \mathrm{~min}$ ), there was a monotonic increase in the number of cells containing FTIC. After $40 \mathrm{~min}$, the increase in dye uptake slowed greatly. After 60 min of permeabilization, $87 \%$ of the cells were positive for FITC, consistent within error, with the percentage of cells expressing $\mathrm{P} 2 \mathrm{Z}$ receptor. Less than $2 \%$ of cells incubated at $37^{\circ} \mathrm{C}$ in the absence of ATP displayed dye uptake, indicating that permeabilization is dependent upon P2Z receptor-associated pore formation. After $60 \mathrm{~min}$ of poration, $88 \pm 3 \%$ of the cells remained viable (Fig. 1D, open squares), comparable to viability in untreated control cells $(91 \% \pm 2 \%)$. These results indicate that TF-1 cells can be reversibly permeabilized via P2Z receptor without a significant decrease in cell viability. 


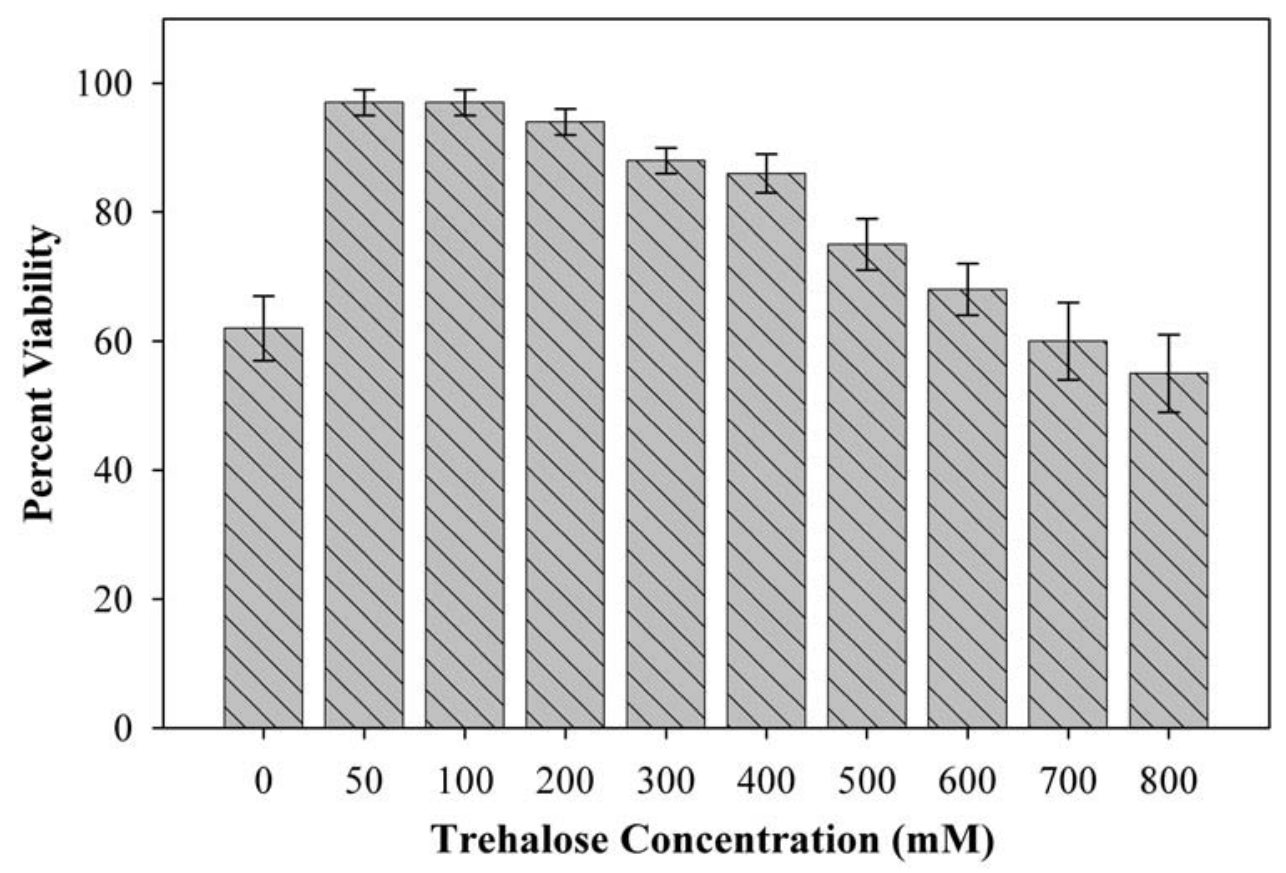

FIG. 2. Optimal trehalose concentration for poration. TF-1 cells were porated in the presence of increasing concentrations of trehalose $(0-800 \mathrm{mM})$ and incubated for $60 \mathrm{~min}$. Viability was determined by trypan blue exclusion. All values are represented as the mean \pm standard deviation for three independent experiments, each with triplicate samples.

Determination of optimal processing conditions for cryopreserving with trehalose

To investigate the effect of trehalose concentration on post-poration viability, TF-1 cells were incubated in poration buffer containing increasing concentrations of trehalose $(0-800$ $\mathrm{mM}$ ) for $60 \mathrm{~min}$ after which pores were closed as described above. Cells incubated without trehalose were $65 \%$ viable after this treatment, (Fig. 2). Cells treated in the presence 50-200 $\mathrm{mM}$ trehalose exhibited the highest postporation viability. At higher concentrations of trehalose, viability decreased with increasing concentrations of trehalose.

To optimize duration of permeabilization and trehalose concentration for cryopreservation, TF-1 cells were permeabilized in the presence of 0-600 $\mathrm{mM}$ trehalose for 0-90 min. After closing pores, cells were frozen in the same trehalose concentrations used for poration. The viability and function of thawed cells were assessed by measuring clonogenic output. For these experiments, cells were transferred directly from the cryopreservation solution into methylcellulose, without dilution or washing steps. The clonogenic potential of treated cells was compared to untreated cells (Fig. 3). Porated cells frozen in the absence of trehalose did not produce any colonies, documenting that a cryoprotectant is required to maintain cell viability during freeze-thawing. There was wide range in the recoveries in samples treated with trehalose, which depended on both the concentration of trehalose and the duration of permeabilization prior to freezing. The greatest clonogenic output (approximately $90 \%$ of control) was observed with HPC porated in the presence of $200 \mathrm{mM}$ trehalose for $60 \mathrm{~min}$ and frozen in a $200 \mathrm{mM}$ trehalose solution. The level of cell survival during freeze-thawing approximates the percentages of cells that could be permeabilized via $\mathrm{P} 2 \mathrm{Z}$ receptor, suggesting that P2Z positive cells survived freeze-thaw.

In contrast, cells frozen and thawed in 10\% DMSO generated $70 \%$ of the colonies produced by untreated control cells. Previous results from our laboratory indicated that approximately $100 \%$ of clonogenic output was maintained during freezing and thawing in 


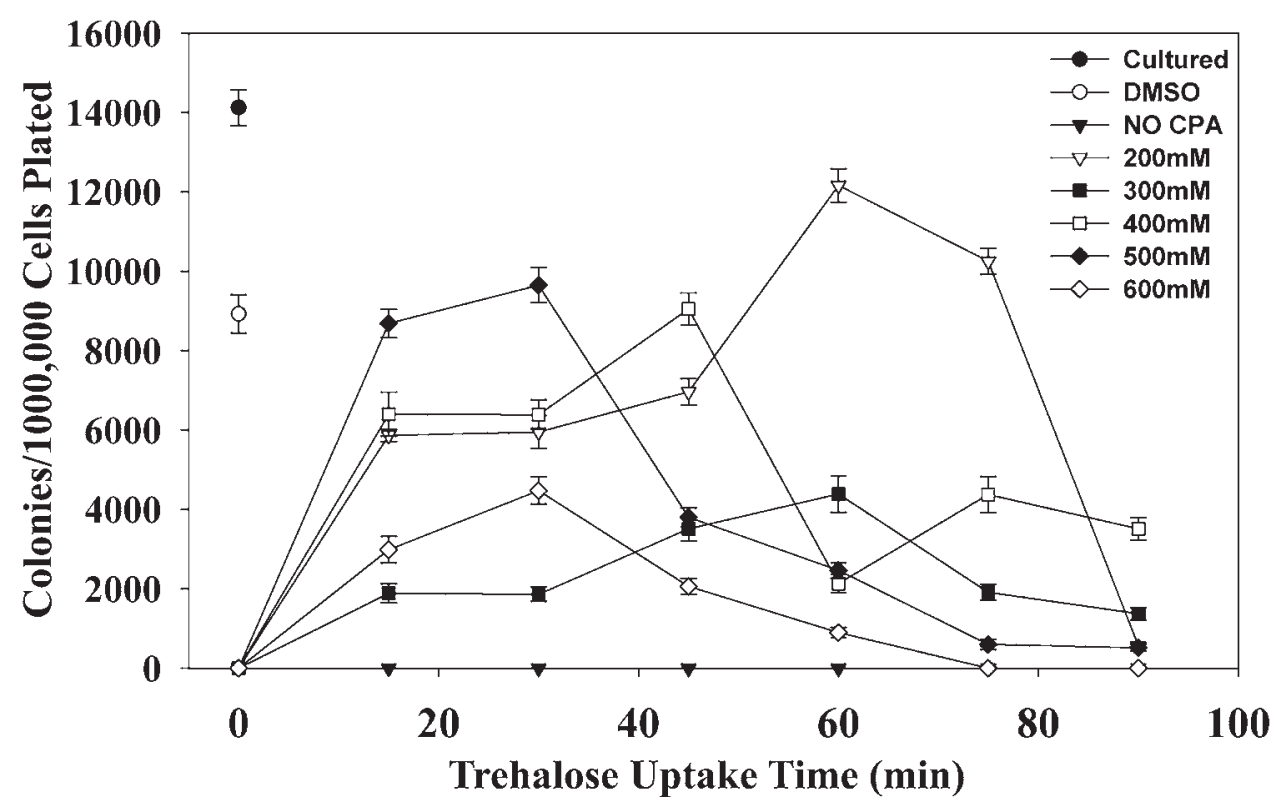

FIG. 3. Determination of optimal processing conditions by colony-forming units (CFU) of TF- 1 cells. TF- 1 cells were porated cells in the presence of trehalose $(0-600 \mathrm{mM})$ for $0-90 \mathrm{~min}$, frozen, and stored at $-80^{\circ} \mathrm{C}$ for $4 \mathrm{months}$. Cells were rapidly thawed at $37^{\circ} \mathrm{C}$ and then transferred into methylcellulose. CFU produced by experimental cells were compared to CFU produced by untreated cells $(100 \%$, solid circle, $n=12)$ and cells frozen in dimethyl sulfoxide (DMSO) (68\%, open circle). The optimal processing conditions were observed with $200 \mathrm{mM}$ trehalose (open triangles, $91 \%)$.

10\% DMSO. The freeze-thawing protocols were identical in both studies, but in the earlier studies the DMSO was washed out from cells prior to CFU assay. In the current study, the cells were directly transferred from the DMSO solution into methylcellulose, which likely resulted in the observed reduction in cell viability.

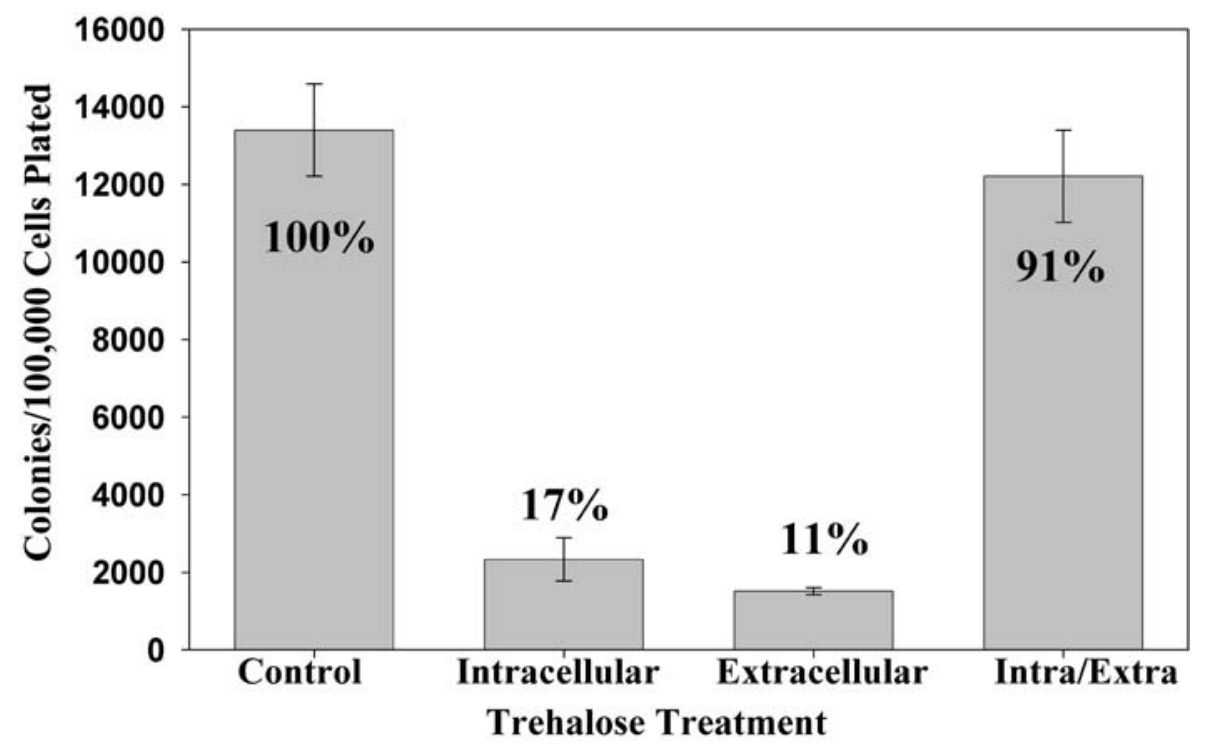

FIG. 4. Effects of intracellular and extracellular trehalose of TF-1 cells during freeze-thawing. TF-1 cells were porated in the presence of $200 \mathrm{mM}$ trehalose for $60 \mathrm{~min}$. One set of samples were frozen immediately with both intracellular and extracellular trehalose. In another set the extracellular trehalose was removed prior to freezing. To a third set of samples of cells, which were not porated, $200 \mathrm{mM}$ extracellular trehalose was added prior to freezing. The frozen samples were stored at $-80^{\circ} \mathrm{C}$, rapidly thawed, and assayed for colony-forming units (CFU). 
Effects of intracellular and extracellular trehalose of TF-1 cells during freeze-thawing

An important consideration for developing cryopreservation protocols for HPC is whether effective cryoprotection requires the cryoprotecting compound to be intracellular, extracellular or both. If only an extracellular cryoprotectant was required, then a permeabilization step would be unnecessary. To address this is- sue, TF-1 cells were porated via $\mathrm{P} 2 \mathrm{Z}$ receptor using optimal conditions (i.e., in the presence of $200 \mathrm{mM}$ trehalose for $60 \mathrm{~min}$ ). After closing the pores, cells were frozen in the presence of both intracellular and extracellular trehalose, or after the extracellular trehalose had been washed away (Fig. 4). Unporated cells were frozen with $200 \mathrm{mM}$ extracellular trehalose. All samples were stored at $-80^{\circ} \mathrm{C}$, as a test of storage stability, for 4 months before thawing. As
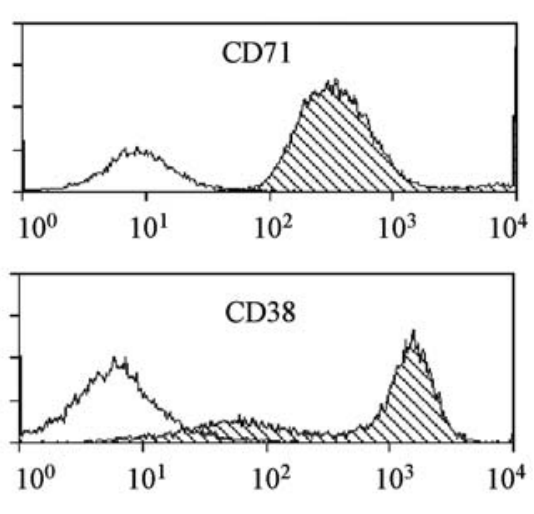

Isotype

Expression at Baseline
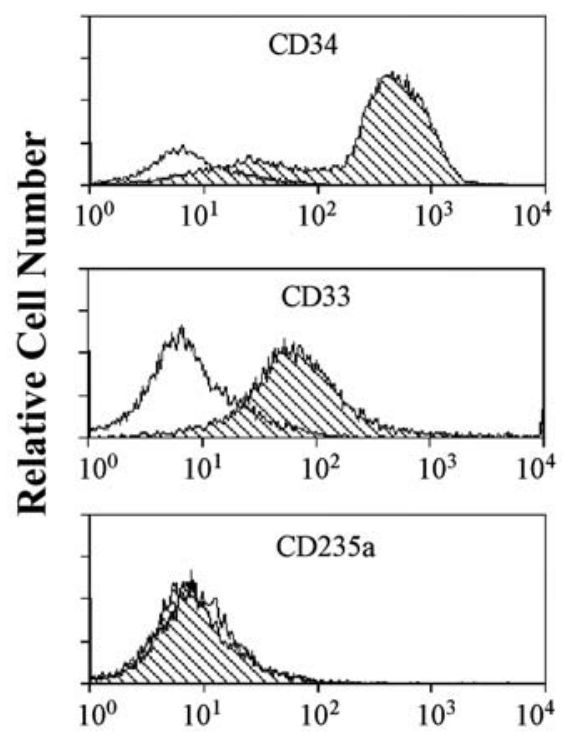

\section{Fluorescence Intensity}

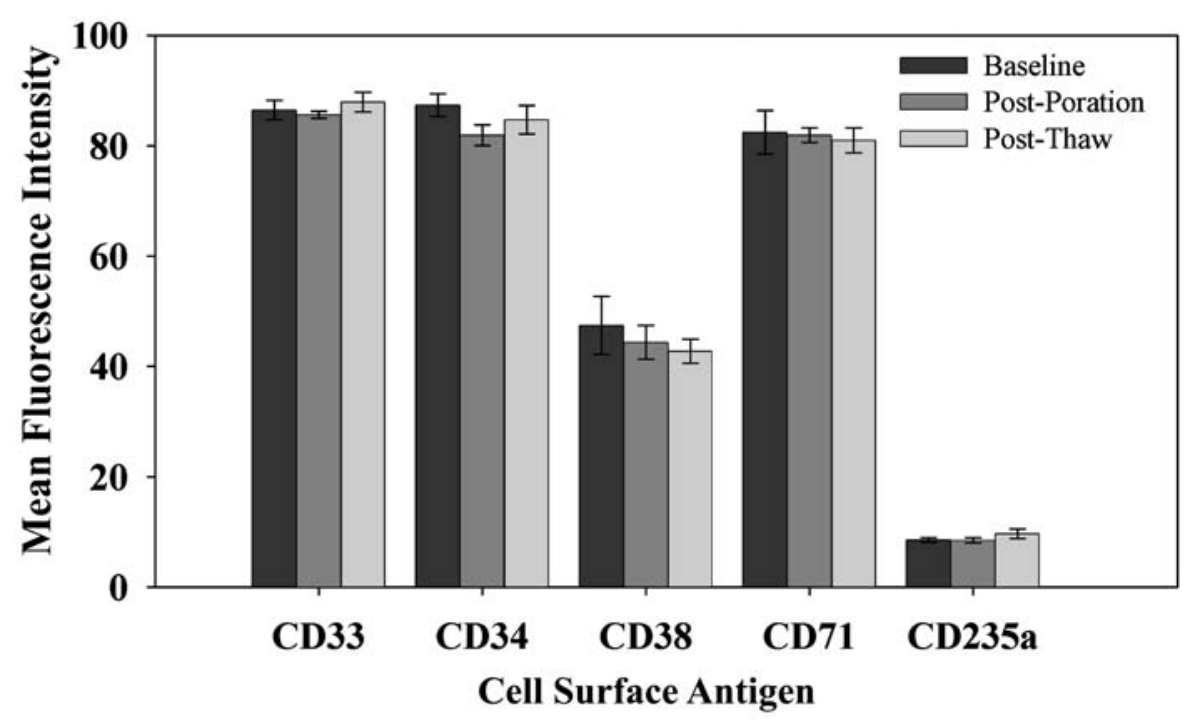

FIG. 5. Evaluation of immunophenotype of TF-1 cells by direct immunofluorescence and flow cytometry. Phenotypic markers were measured in untreated TF-1 cells, after poration, and after freeze-thawing. Makers for differentiation, activation, and proliferation were assessed (see text). Untreated TF-1 cells were positive for CD33, CD34, CD38, CD71, and negative for CD235a. There were no significant alterations in phenotypic markers following poration or freeze-thawing. All values are represented as the mean \pm standard deviation of three independent experiments each with quadruplicate samples. 
shown in Figure 4, both intracellular and extracellular trehalose were needed to maximize cryopreservation of TF-1 cells.

These results demonstrate that trehalose is required on both sides of the plasma membrane to protect it from damage, as well as in the cytoplasm to stabilize intracellular components during freeze-thawing. Previous studies by Crowe and colleagues demonstrated that trehalose present on both sides of isolated membrane vesicles and yeast membrane bilayers not only maximizes protection during freezing but also during desiccation. ${ }^{29-32}$ It is possible that trehalose on both sides of the plasma membrane, as well as in the cytoplasm may not only prevent damage to the membrane and intracellular components during freeze-thawing, but may also afford protection for HPC survival in a desiccated state.

\section{Effect of poration and freeze-thawing on immunophenotype}

To investigate if poration and freeze-thawing alter phenotypic makers of differentiation, activation and proliferation, we performed immnuophenotypic analysis ${ }^{33}$ by flow cytometry. Markers chosen for this step were CD34, CD33, CD38, CD71, and CD235a. CD34 expression is highest in relatively immature hematopoietic stem and progenitor cells and is often used to select cells with the hematopoietic potential required for hematopoietic reconstitution. CD38 can be used as an activation marker for proliferating cells and CD33 is an early myeloid marker. CD71 expression, the transferrin receptor, can be used to study cells in transition from resting to a proliferative state. CD235a (glycophorin A) is expressed on human red blood cells and erythroid precursor cells. At baseline, untreated TF-1 cells were shown to express CD34, CD33, CD38, CD71 but not CD235a (Fig. 5A). The relative levels of these antigens document that TF-1 cells are hematopoietic and myeloid progenitors $1\left(\mathrm{CD} 34^{+}\right.$and $\left.\mathrm{CD} 33^{+}\right)$, activated $\left(\mathrm{CD} 38^{+}\right)$, highly proliferative $\left(\mathrm{CD}^{+} 1^{+}\right)$, but are CD235a negative. After $60 \mathrm{~min}$ permeabilization in the presence of $200 \mathrm{mM}$ trehalose, pores were closed and reanalyzed immediately after por- ation and after freeze-thawing (Fig. 5B). The expression levels of phenotypic markers, as measured with flow cytometry, demonstrate that cell activation, proliferative status, and differentiation were not significantly altered following P2Z receptor activation, loading of intracellular trehalose, and freeze-thawing compared to untreated control.

Potential application of poration via the P2Z receptor to cryopreservation of other cell types

Expression and activation of the P2Z receptor has also been investigated in nonhematopoietic tissue. A study by Collo et al. ${ }^{19}$ demonstrates that the $\mathrm{P} 2 \mathrm{Z}$ receptor present in the brain are expressed by microglia and ependymal cells rather than neurons. Since microglia are the resident macrophages of the brain, it is consistent with the finding of $\mathrm{P} 2 \mathrm{Z}$ receptor in peripheral macrophages and macrophage-like cells found in the lung and spleen. ${ }^{18}$ This receptor has also been described in primary human cells such as fibroblasts, ${ }^{34}$ fetal keratinocytes, ${ }^{35}$ vascular endothelial cells, ${ }^{36}$ and vein smooth muscle. ${ }^{37}$ Cells derived from rodents, such as astrocytes, medulla oblongata, ${ }^{38}$ parotid acinar cells, ${ }^{39}$ and spinal cord cells ${ }^{38}$ along with immortal microglial, ${ }^{40} \mathrm{CHO}-\mathrm{K} 1,{ }^{40}$ and mesangial cells ${ }^{19}$ have also been permeabilized with P2Z receptor. With such a wide range of cells already known to express this protein, there is potentially a wide application of cryopreserving a variety cells with trehalose using this method and development in freeze-drying applications.

\section{ACKNOWLEDGMENTS}

The authors would like to acknowledge the technical assistance of Karen Helm and Michael Ashton of the University of Colorado Cancer Center Flow Cytometry Core Facility, which is supported by National Institutes of Health grant 5P30CA46934-15. We also acknowledge the Defense Advanced Research Projects Agency/Naval Research Laboratories Grant Number N00173-01-1 G011 for providing funding for these studies. 


\section{REFERENCES}

1. Voermans C, van Hennik PB, van Der Schoot CE. Homing of human hematopoietic stem and progenitor cells: New insights, new challenges? J Hematother Stem Cell Res. 2001;10:725-738.

2. Woods E, Liu J, Derrow CW, et al. Osmometric and permeability characteristics of human placental/umbilical cord blood CD34+ cells and their application to cryopreservation. J Hematother Stem Cell Res 2000;9:161-173.

3. Beaujean F, Bourhis JH, Bayle CH, et al. Successful cryopreservation of purified autologous CD34+ cells: Influence of freezing parameters on cell recovery and engraftment. Bone Marrow Transplant 1998;22:10911096.

4. Shpall E, LeMaistre CF, Holland K, et al. A prospective randomized trial of buffy coat versus CD34-selected autologous bone marrow support in high-risk breast cancer patients receiving high-dose chemotherapy. Blood 1997;90:4313-4320.

5. Davis J, Rowley S, Braine H, et al. Clinical toxicity of cryopreserved bone marrow graft infusion. Blood 1990;75:781-786.

6. Stroncek D, Fautsch SK, Lasky LC, et al. Adverse reactions in patients transfused with cryopreserved marrow. Transfusion 1991;31:521-526.

7. Halle P, Tournilhac O, Knopinska-Posluszny W, et al. Uncontrolled-rate freezing and storage at $-80^{\circ} \mathrm{C}$, with only 3.5\% DMSO in cryoprotective solution for 108 autologous peripheral blood progenitor cell transplantations. Transfusion 2001;41:667-673.

8. Massimo M, Fortunato M, Giuseppe M, et al. Fractionated infusions of cryopreserved stem cells may prevent DMSO-induced major cardiac complications in graft recipients. Haematologica 1996;81:59-61.

9. Carral A, de la Rubia J, Martin G, et al. Factors influencing the collection of peripheral blood stem cells in patients with acute myeloblastic leukemia and nonmyeloid malignancies. Leuk Res 2003;27:5-12.

10. Guo N, Puhlev I, Brown DR, et al. Trehalose expression confers desiccation tolerance on human cells. Nat Biotechnol 2000;18:168-171.

11. Beattie GM, Crowe JH, Lopez AD, et al. Trehalose: A cryoprotectant that enhances recovery and preserves function of human pancreatic islets after long-term storage. Diabetes 1997;46:519-523.

12. Oliver AE, Jamil K, Crowe JH, et al. Loading human mesenchymal stem cells with trehalose by fluidphase endocytosis. Cell Preservation Technol 2005;2: 35-49.

13. Russo M, Bayley H, Toner M. Reversible permeabilization of plasma membranes with an engineered switchable pore. Nat Biotechnol 1997;15:278-282.

14. Eroglu A, Russo MJ, Bieganski R, et al. Intracellular trehalose improves the survival of cryopreserved mammalian cells. Nat Biotechnol 2000;18:163-167.

15. Buchanan SS, Gross SA, Acker, JP, et al. Cryopreservation of stem cells using trehalose: Evaluation of the method using a human hematopoietic cell line. Stem Cells Development 2004;13:295-305.

16. Gordon JL. Extracellular ATP: Effects, sources and fate. Biochem J 1986;233:309-319.

17. Steinberg TH, Silverstein SC. ATP permeabilization of the plasma membrane. Methods Cell Biol 1989;31: 45-61.

18. Surprenant A, Rassendren R, Kawashima E, et al. The cytolytic P2Z receptor for extracellular ATP identified as a P2X receptor (P2X7). Science 1996;272:735738.

19. Collo G, Neidhart S, Kawashima E, et al. Tissue distribution of the $\mathrm{P} 2 \mathrm{X7}$ receptor. Neuropharmacol 1997;36:1277-1283.

20. Coutinho-Silva R, Anastficio Alves L, Savino W, et al. A cation non-selective channel induced by extracellular ATP in macrophages and phagocytic cells of the thymic reticulum. Biochim Biophys Acta 1996;1278: 125-130.

21. Nihei OK, Savino, Wilson and Alves, Luiz Anastacio. Procedures to characterize and study $\mathrm{P} 2 \mathrm{Z} / \mathrm{P} 2 \mathrm{X} 7$ purinoceptor: Flow cytometry as a promising practical, reliable tool. Mem Inst Oswaldo Cruz 2000;95: 415-428.

22. Smart ML, Gu B, Panchal RG, et al. P2X7 receptor cell surface expression and cytolytic pore formation are regulated by a distal C-terminal region. J Biol Chem 2003;278:8853-8860.

23. Menze MA, Clavenna M, Hand SC. Depression of cell metabolism and proliferation by membrane-permeable and -impermeable modulators: Role for AMP-toATP ratio. Am J Physiol (Regul Integr Comp Physiol) 2005;288:R501-R510.

24. Hand SC, Menze M. A preservation of eukaryotic cells. 2004. U.S. Pat. App. No. 10/965,039.

25. Di Virgilio F. The P2Z purinoceptor: An intriguing role in immunity, inflammation and cell death. Immunol Today. 1995;16:524-528.

26. Di Virgilio F, Chiozzi P, Ferrari D, et al. Nucleotide receptors: an emerging family of regulatory molecules in blood cells. Blood 2001;97:587-600.

27. Suh B-C, Kim J-S, Namgung U, et al. P2X7 Nucleotide receptor mediation of membrane pore formation and superoxide generation in human promyelocytes and neutrophils. J Immunol 2001;166:6754-6763.

28. Kitamura T, Tange T, Terasawa T, et al. Establishment and characterization of a unique human cell line that proliferates dependently on GM-CSF, IL-3, or erythropoietin. J Cell Physiol 1989;140:323-334.

29. Crowe JH, Panek AD, Crowe LM, et al. Trehalose transport in yeast cells. Biochem Int 1991;24:721-730.

30. De Araujo PS, Panek AC, Crowe JH, et al. Trehalosetransporting membrane vesicles from yeasts. Biochem Int 1991;24:731-737.

31. Eleutherio EC, Araujo PS, Panek AD. Role of the trehalose carrier in dehydration resistance of Saccharomyces cerevisiae. Biochim Biophys Acta 1993;1156: 263-266.

32. Cuber R, Eleutherio EC, Pereira MD, et al. The role 
of the trehalose transporter during germination. Biochim Biophys Acta 1997;1330:165-171.

33. Redelman D. Flow cytometric analyses of cell phenotypes. In: Stewart CC, Nicholson, JKA, eds. Immunophenotyping. 1st ed. New York: Wiley-Liss, 2000:49-82.

34. Solini A, Chiozzi P, Morelli A, et al. Human primary fibroblasts in vitro express a purinergic P2X7 receptor coupled to ion fluxes, microvesicle formation and IL-6 release. J Cell Sci 1999;112:297-305.

35. Greig AVH, Linge C, Cambrey A, et al. Purinergic receptors are part of a signaling system for keratinocyte proliferation, differentiation, and apoptosis in human fetal epidermis. J Invest Dermatol 2003;121:1145-1149.

36. El-Moatassim C, Dornand J, Mani JC. Extracellular ATP and cell signalling. Biochim Biophys Acta 1992; 1134:31-45.

37. Cario-Toumaniantz C, Loirand G, Ladoux A, $t$ al. P2X7 receptor activation-induced contraction and lysis in human saphenous vein smooth muscle. Circ Res 1998;83:196-203.

38. Deuchars SA, Atkinson L, Brooke RE, et al. Neuronal $\mathrm{P} 2 \mathrm{X} 7$ receptors are targeted to presynaptic terminals in the central and peripheral nervous systems. J Neurosci 2001;21:7143-7152.

39. Li Q, Luo X, Zeng W, et al. Cell-specific behavior of P2X7 receptors in mouse parotid acinar and duct cells. J Biol Chem 2003;278:47554-47561.

40. Michel A, Chessell IP, Hibell AD, et al. Identification and characterization of an endogenous P2X7 (P2Z) receptor in CHO-K1 cells. Br J Pharmacol 1998;125: 1194-1201.

Address reprint requests to: John F. Carpenter, Ph.D. Center for Pharmaceutical Biotechnology and Department of Pharmaceutical Sciences University of Colorado Health Sciences Center Campus Box C-238 4200 East Ninth Avenue Denver, CO 80262

E-mail: john.carpenter@uchsc.edu 